\title{
Micronutrient cooperation in the suppression of HIV production in chronically and latently infected cells
}

\author{
RAXIT J. JARIWALLA, BHAKTI GANGAPURKAR, ANUPRIYA PANDIT, \\ TATIANA KALINOVSKY, ALEKSANDRA NIEDZWIECKI and MATTHIAS RATH \\ Dr Rath Research Institute, Santa Clara, CA 95050, USA
}

Received December 24, 2009; Accepted February 8, 2010

DOI: $10.3892 / \mathrm{mmr} 00000268$

\begin{abstract}
Nutrients are known to display pharmacologic activity against viruses and to exert cooperative effects in cells. To study the influence of nutrient cooperation on HIV production in chronically infected $\mathrm{T}$ lymphocytes, we evaluated the individual and combined effects of nutrients on HIV-1 reverse transcriptase (RT) released into the culture supernatant. In unstimulated cells, low concentrations of single nutrients, namely ascorbic acid (AA), green tea polyphenols (GT) or lysine, did not significantly suppress HIV-1 RT production. However, when GT $(25 \mu \mathrm{g} / \mathrm{ml})$ and AA (32-64 $\mu \mathrm{g} / \mathrm{ml})$ were combined and applied to cells, extracellular RT was significantly reduced relative to the control. Combining GT $(25 \mu \mathrm{g} / \mathrm{ml})$ with lysine $(25 \mu \mathrm{g} / \mathrm{ml})$ also reduced the RT level to a greater extent (51\% of control) than was observed wih lysine alone, and the addition of AA $(16 \mu \mathrm{g} / \mathrm{ml})$ to the combination further decreased RT to $17 \%$ of the control $(\mathrm{p}=0.06)$. Under the same assay conditions, the nucleoside analog azidothymidine did not significantly suppress HIV production at low to moderate concentrations $(0.5-1.0 \mu \mathrm{g} / \mathrm{ml})$, but did reduce the RT level to $40 \%$ of the control $(\mathrm{p}=0.02)$ at the highest dose tested $(2 \mu \mathrm{g} / \mathrm{ml})$. In unstimulated cells as well as in latently infected cells stimulated with mitogen (PMA or TNF- $\alpha$ ), a nutrient mixture containing GT, AA and amino acids imparted significantly greater RT suppression than equivalent concentrations of key individual components. Nutrient effects on RT suppression were virus-specific and were not due to non-specific cellular toxicity. These results suggest that relatively non-toxic micronutrient combinations are more potent than single nutrients in suppressing virus production in chronically infected $\mathrm{T}$ cells, indicating that the constituent nutrients have a cooperative effect in HIV inhibition.
\end{abstract}

Correspondence to: Dr Aleksandra Niedzwiecki, Dr Rath Research Institute, 1260 Memorex Drive, Santa Clara, CA 95050, USA

E-mail: author@drrath.com

Key words: HIV, micronutrients, nutrient cooperation, virus suppression

\section{Introduction}

HIV infection and AIDS have become a worldwide pandemic over the past two decades, with more than 33 million people currently infected worldwide (1). The prevalence of HIV is increasing rapidly in sub-Saharan Africa and in southern and eastern Asia. AIDS is the leading cause of death in Africa and the fourth leading cause of death worldwide (1). Currently, there are two recognized strains of HIV, HIV-1 and -2; HIV-1 is the more pathogenic form and the principal cause of AIDS (2). The scope of the global HIV-1 epidemic has created an urgent need for effective treatment to protect against viral infection and to control disease progression.

The main therapeutic strategy against HIV has been the development of antiretroviral (ARV) drugs targeted at different steps in viral replication (3). The use of individual and combinations of ARV drugs is capable of delaying disease progression depending on the CD4 cell count at the commencement of treatment, but has not eradicated the disease (4). Furthermore, the virus mutates and develops resistance to ARV drugs, so new agents or combinations must be prescribed (3). In addition, ARV drugs are known to be toxic and to have many debilitating side effects $(3,5)$, supporting the need for non-toxic therapy to block virus multiplication.

Since the emergence of the AIDS epidemic, it has been found that protein calorie malnutrition and specific micronutrient abnormalities are common in patients with HIV and AIDS (6,7). Furthermore, in a group of HIV-positive children, the levels of specific antioxidants, including vitamins $\mathrm{A}, \mathrm{C}$ and $\mathrm{E}$, were found to be significantly depressed, secondary to oxidative stress caused by free radicals (8). In other studies, vitamins, minerals, amino acids and other micronutrients have been shown to modulate HIV and other viral infections through several different mechanisms (9-13). In particular, vitamin $\mathrm{C}$ has been reported to have significant antiviral activity against various viruses (14) and to exert anti-HIV activity clinically (15-17) and experimentally (9-11).

Since the focus of anti-HIV drug therapy has been on the inhibition of various steps in viral replication during acute infection, little attention has been directed towards blocking chronic or latent virus expression. In the latter case, the virus is known to remain quiescent in the reservoirs of latently infected cells, even in the presence of ARV drugs. Consequently, there is a need for new agents that block chronic 
or latent virus expression. In this investigation, we studied the activity of specific micronutrients (viz. ascorbic acid, green tea extract, lysine, proline and arginine) on HIV-1 production in chronically and latently infected $\mathrm{T}$ lymphocytes by assaying the ability of different micronutrient combinations to suppress the release of virus-associated RT in the culture supernatant. The rationale for choosing to use these nutrients in a combinatorial approach was based on their anti-viral properties (see Discussion) and their ability to impact different physiologic processes in cells, which may provide cooperative effect(s) in viral infection. In this study, we report the individual and combined anti-HIV actions of nutrients in two independent cell lines of chronic and latent infection.

\section{Materials and methods}

Test reagents. The micronutrient mixture (NM) was composed of the following in the ratio indicated: vitamin $\mathrm{C}$ (as ascorbic acid and as $\mathrm{Mg}, \mathrm{Ca}$ and palmitate ascorbate), $700 \mathrm{mg}$; L-lysine, 1,000 mg; L-proline, $750 \mathrm{mg}$; L-arginine, $500 \mathrm{mg}$; $\mathrm{N}$-acetyl cysteine, $200 \mathrm{mg}$; standardized green tea extract (80\% polyphenol), 1,000 mg; selenium, $30 \mu \mathrm{g}$; copper, $2 \mathrm{mg}$; manganese, $1 \mathrm{mg}$. Individual components, namely green tea extract powder and ascorbic acid, were obtained from Vita Tech International, and proline, arginine and lysine were from Sigma (St. Louis, MO). Azidothymidine was obtained from the NIH AIDS Research and Reference Reagent Program (Germantown, MD). Stock solutions ( $2 \mathrm{X}$ concentration) of test reagents were freshly prepared before use by dissolving the reagent(s) in complete RPMI growth medium, and were sterilized by passage through a $0.2-\mu \mathrm{m}$ filter. Mock solution (untreated control) consisted of RPMI growth medium only (lacking test reagent).

\section{Cell culture and treatments}

Treatment of unstimulated chronically infected T cells. H9/ $\mathrm{HTLV}_{\mathrm{III}}$ cells, which constitutively produce and release virus into the culture supernatant, were obtained from the NIH AIDS Research and Reference Reagent Program. Cells were grown in RPMI-1640 medium with $2 \mathrm{mM}$ L-glutamine, $1 \mathrm{mM}$ pyruvate and $10 \mathrm{mM}$ HEPES (90\%) supplemented with $10 \%$ (vol/vol) fetal calf serum, penicillin $(100 \mathrm{U} / \mathrm{ml})$ and streptomycin $(100 \mu \mathrm{g} / \mathrm{ml})$ in a humidified incubator equilibrated with $95 \%$ air and $5 \% \mathrm{CO}_{2}$. Exponentially growing cells $\left(2 \times 10^{6}\right.$ cells $\left./ \mathrm{ml}\right)$ were seeded in 24 -well plates $(0.5 \mathrm{ml}$ cell suspension/well) and treated with various concentrations of the test compound(s) $(0.5 \mathrm{ml}$ of $2 \mathrm{X}$ strength stock) in triplicate wells at each dose. The $\mathrm{pH}$ of the NM, ascorbic acid (AA), green tea extract (GT), lysine (Lys), proline (Pro) and arginine (Arg) solutions applied to cells was in the physiological range. Untreated controls received an equivalent amount of growth medium. The plates were returned to the incubator and, at defined time intervals, the cultures were assessed for the degree of cytotoxicity caused by the test compound(s) and for the level of extracellular RT in the culture supernatant (described below). Culture media and components were purchased from Gibco (Invitrogen Corp., Carlsbad, CA).

Treatment of latently infected $T$ cells and stimulation with PMA or TNF- $\alpha$. ACH-2, an HIV-infected latent T-cell clone of CEM cells producing very low levels of virus, was also obtained from the NIH AIDS Research and Reference Reagent Program. Cells were grown in RPMI-1640 medium with $10 \mathrm{mM}$ HEPES, $2 \mathrm{mM}$ L-glutamine and $1 \mathrm{mM}$ pyruvate (90\%) supplemented with heat-inactivated fetal bovine serum $(10 \%)$, penicillin $(100 \mathrm{U} / \mathrm{ml})$ and streptomycin $(100 \mu \mathrm{g} / \mathrm{ml})$ in a humidified incubator equilibrated with $95 \%$ air and $5 \% \mathrm{CO}_{2}$. Exponentially growing cells were seeded in 24-well cluster plates and treated with nutrients as described above for the $\mathrm{H} 9$ / HTLV-III ${ }_{B}$ cells. After $24 \mathrm{~h}$, phorbol 12-myristate 13-acetate (PMA, $100 \mathrm{ng} / \mathrm{ml})$ or tumor necrosis factor $\alpha(\mathrm{TNF}-\alpha 1 \mathrm{ng} /$ $\mathrm{ml}$ ) was added to induce latent virus, and the cells were further incubated for 24 or $48 \mathrm{~h}$. Following these incubation periods, cell suspensions were harvested for the estimation of viral RT activity in the culture supernatant and were assessed for cytoxicity in cell pellets (described below).

Assay of extracellular reverse transcriptase level in culture supernatant. Suspension cells were centrifuged at $1,000 \mathrm{x} g$ for $10 \mathrm{~min}$ in a refrigerated centrifuge at $4^{\circ} \mathrm{C}$. The supernatant was transferred into a fresh tube, and the cell pellet was used for measuring protein biomass (cytotoxicity). Virus particles in the culture supernatant were pelleted by centrifugation in a refrigerated microfuge $\left(19,000 \mathrm{x}\right.$ g for $2 \mathrm{~h}$ at $\left.4^{\circ} \mathrm{C}\right)$, resuspended in $100 \mu \mathrm{l}$ of lysis buffer (Tris-buffer containing $0.5 \%$ Triton $\mathrm{X}-100, \mathrm{pH} 7.8$ ) and incubated at $25^{\circ} \mathrm{C}$ for $30 \mathrm{~min}$ to solubilize viral particles. Solubilized pellets $(40 \mu \mathrm{l})$ were assayed for RT activity using a non-radioactive colorimetric enzyme immunoassay (Roche Applied Science, Indianapolis, IN). RT activity was expressed as nanograms/well.

Protein biomass (cytotoxicity) assay and selectivity index. To determine whether the antiviral effect of the micronutrients was a specific effect of the agents or whether it was due to cytotoxicity, we determined a selective index, i.e., the ratio of cytotoxicity value to antiviral efficacy value. A cytotoxicity assay based on measuring total biomass was conducted by staining cellular proteins with sulforhodamine B dye as described by Skehan et al (18). Briefly, HIV-1-infected T lymphocytes were treated with the test reagents in replicate at each concentration. After 24 or $48 \mathrm{~h}$, the cells were washed, fixed with $50 \%$ trichloroacetic acid, rinsed, drip-dried and stained with sulforhodamine B. The incorporated dye was liberated from the cells in a Tris base solution, and the total protein (biomass) was determined by measuring absorbance at a wavelength of $565 \mathrm{~nm}$. The degree of cytotoxicity by the test reagent was defined as the change in absorbance relative to the untreated control culture. The selective index was the ratio of total cell protein to HIV-1 RT activity in the culture supernatant.

All experiments involving HIV-infected cell lines, the processing of cell culture supernatants and the sedimentation of virus and pellets were carried out using Biosafety level 2 (BSL 2) facilities, practices and safety equipment, as described in the CDC-NIH Guide for Biosafety in Microbiological and Biomedical Laboratories.

Statistical analysis. The results for each representative study are expressed as the mean \pm standard deviation for the groups. Data were analyzed using the independent sample 2-tailed t-test. Pearson's correlation coefficients were determined for 
Table I. Effects of test agents on the selectivity index (mean ratio of total cell protein/HIV-1 RT units) in H9/HTLV-III $\mathrm{B}_{\mathrm{B}}$ cells.

\begin{tabular}{|c|c|c|c|}
\hline Test agents/combinations $(\mu \mathrm{g} / \mathrm{ml})$ & Mean ratio & Standard deviation & Percentage of control \\
\hline NM 0 (control) & 4.36 & 0.359 & 100.0 \\
\hline NM 25 & 4.99 & 2.340 & 114.0 \\
\hline NM 50 & 7.68 & 0.459 & 176.0 \\
\hline NM 100 & 7.37 & 2.340 & 169.0 \\
\hline NM 200 & 9.61 & 0.570 & $220.0^{\mathrm{a}}$ \\
\hline GT 0 (control) & 4.36 & 0.359 & 100.0 \\
\hline GT 12.5 & 3.95 & 0.567 & 90.5 \\
\hline GT 25 & 4.08 & 0.748 & 93.6 \\
\hline GT 50 & 6.48 & 3.960 & $149.0^{\mathrm{b}}$ \\
\hline GT $0+$ AA 0 (control) & 1.67 & 0.500 & 100.0 \\
\hline GT $25+$ AA 16 & 3.62 & 1.720 & 217.0 \\
\hline GT $25+$ AA 32 & 3.22 & 1.700 & 193.0 \\
\hline GT 25 + AA 64 & 3.93 & 1.310 & $235.0^{\mathrm{b}}$ \\
\hline Lys $0+$ GT $0+$ AA 0 (control) & 4.78 & 2.870 & 100.0 \\
\hline Lys $25+$ GT $0+$ AA 0 & 2.26 & 2.030 & 47.2 \\
\hline Lys $25+$ GT $25+$ AA 0 & 4.19 & 1.520 & 87.8 \\
\hline Lys $0+$ GT 25 + AA 16 & 8.65 & 5.700 & 181.0 \\
\hline Lys $25+$ GT $25+$ AA 16 & 3.02 & 1.320 & $63.2^{\mathrm{c}}$ \\
\hline Pro $0+\operatorname{Arg} 0+$ Lys $0+$ GT $0+$ AA 0 (control) & 2.43 & 0.560 & 100.0 \\
\hline Pro $18+\operatorname{Arg} 12+$ Lys $25+$ GT $0+$ AA 0 & 1.85 & 0.192 & 41.2 \\
\hline Pro $18+\operatorname{Arg} 12+$ Lys $25+$ GT $25+$ AA 0 & 2.57 & 1.060 & 105.8 \\
\hline Pro $18+\operatorname{Arg} 12+$ Lys $25+$ GT 25 + AA 32 & 2.71 & 0.387 & $111.5^{\mathrm{b}}$ \\
\hline AZT 0 (control) & 9.40 & 4.330 & 100.0 \\
\hline AZT 0.5 & 14.2 & 4.270 & 151.0 \\
\hline AZT 1.0 & 17.8 & 13.90 & 189.0 \\
\hline AZT 2.0 & 16.8 & 8.730 & $179.0^{\mathrm{b}}$ \\
\hline
\end{tabular}

${ }^{a}$ Increased ratio relative to control, statistically significant ( $\left.\mathrm{p}=0.009\right)$; ${ }^{\mathrm{b}}$ Increased ratio relative to control, insignificant change; ${ }^{\mathrm{c} D e c r e a s e d}$ ratio relative to control, insignificant change. NM, nutrient mixture; GT, green tea extract; AA, ascorbic acid; Lys, lysine; Pro, proline; Arg, arginine; AZT, azidothymidine.

dose-dependent studies using MedCalc Software (Maiakerke, Belgium).

\section{Results}

Studies in the unstimulated chronically infected H9/HTLV$\mathrm{III}_{B} \mathrm{~T}$ cell line

Effect of green tea extract on HIV-1 RT level in culture supernatant and ratio of total cell protein/HIV-1 RT units. To evaluate individual nutrient classes, the effect of GT containing polyphenols was tested. GT suppressed HIV-1 production with an increased concentration in the $12.5-50 \mu \mathrm{g} /$ $\mathrm{ml}$ range (correlation $\mathrm{r}=-0.6421, \mathrm{p}=0.0244$ ), with significant suppression noted at the high dose. Extracellular RT was reduced to $25 \%(\mathrm{p}=0.01)$ of the control value with $50 \mu \mathrm{g} /$ $\mathrm{ml} \mathrm{GT}$, as shown in Fig. 1A. The ratio of total cell protein/ HIV-1 RT was stable at low GT concentrations (correlation $\mathrm{r}=0.4320, \mathrm{p}=0.1608)$, but increased to $149 \%(\mathrm{p}=0.23)$ of the control value at the concentration of $50 \mu \mathrm{g} / \mathrm{ml}$, as shown in Table I.
Effect of ascorbic acid and green tea extract on HIV-1 RT level and ratio of total cell protein/HIV-1 RT units. Next, AA was tested alone and in combination with GT. AA alone did not significantly reduce the extracellular HIV-1 RT level in the low concentration range tested (16-64 $\mu \mathrm{g} / \mathrm{ml}$, data not shown). However, when combined with $25 \mu \mathrm{g} / \mathrm{ml}$ GT (correlation $\mathrm{r}=-0.7288, \mathrm{p}=0.0072$ ), the suppressive effect of low AA concentrations on the HIV-1 RT level increased, as shown in Fig. 1B. At $64 \mu \mathrm{g} / \mathrm{ml}$ of AA in the presence of GT, the RT level was reduced to $24 \%$ of the control value $(\mathrm{p}=0.013)$ compared to a reduction to $49 \%$ of the control value $(p=0.55)$ at a concentration of $16 \mu \mathrm{g} / \mathrm{ml} \mathrm{AA}$ with GT. The ratio of total cell protein/HIV-1 RT units increased slightly but insignificantly with an increase in the concentration of AA used either alone or with GT (Table I).

Effect of lysine, green tea and ascorbic acid on HIV-1 RT level in culture supernatant and ratio of total cell protein/ $H I V-1$ RT units. Individually, Lys at 12.5 and $25 \mu \mathrm{g} / \mathrm{ml}$ had insignificant effects on extracellular HIV-1 RT levels and on 

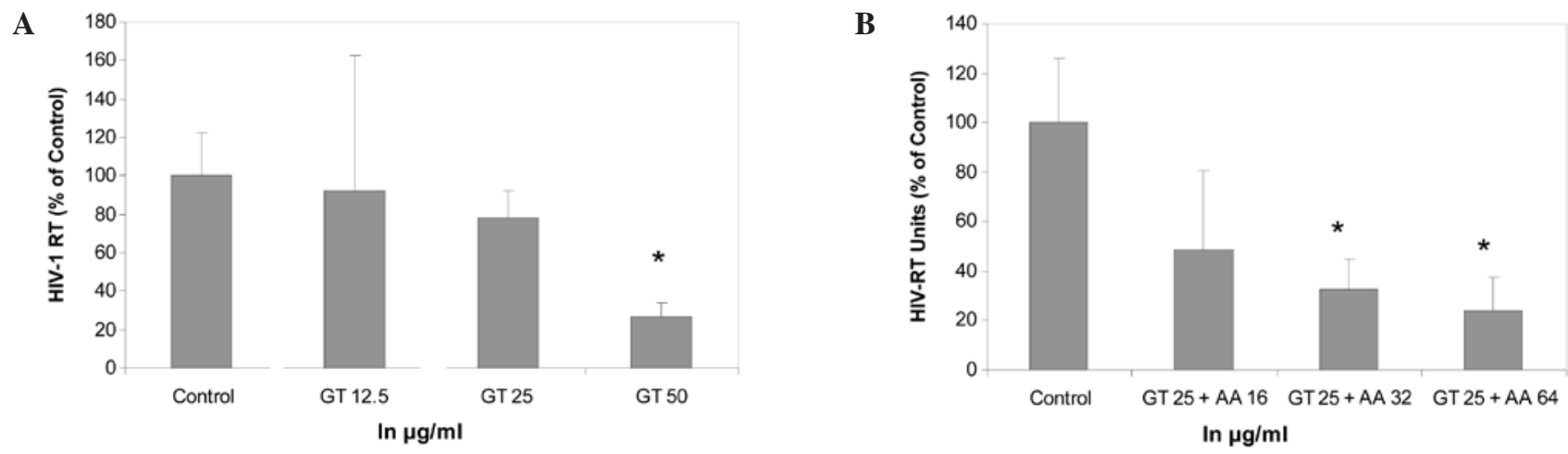

Figure 1. Effect of green tea extract (GT) alone (A) and in combination with increasing ascorbic acid (AA) concentrations (B) on HIV-1 RT level in the culture supernatant of $\mathrm{H} 9 / \mathrm{HTLV}-\mathrm{III}_{\mathrm{B}}$ cells. Shown is the residual RT level as a percentage of the control. GT suppressed the HIV-1 RT level at a high concentration of $50 \mu \mathrm{g} / \mathrm{ml}$, with $\mathrm{p}=0.01$ relative to the control. The suppressive effect of GT on the HIV-1 RT level increased when combined with increasing AA concentrations (correlation $\mathrm{r}=-0.7288, \mathrm{p}=0.0072$ ), with $\mathrm{p}=0.013$ at $64 \mu \mathrm{g} / \mathrm{ml} \mathrm{AA}$ and $\mathrm{p}=0.55$ at $16 \mu \mathrm{g} / \mathrm{ml}$ AA relative to the control. " $\mathrm{p}=0.05$ or better compared to the control.

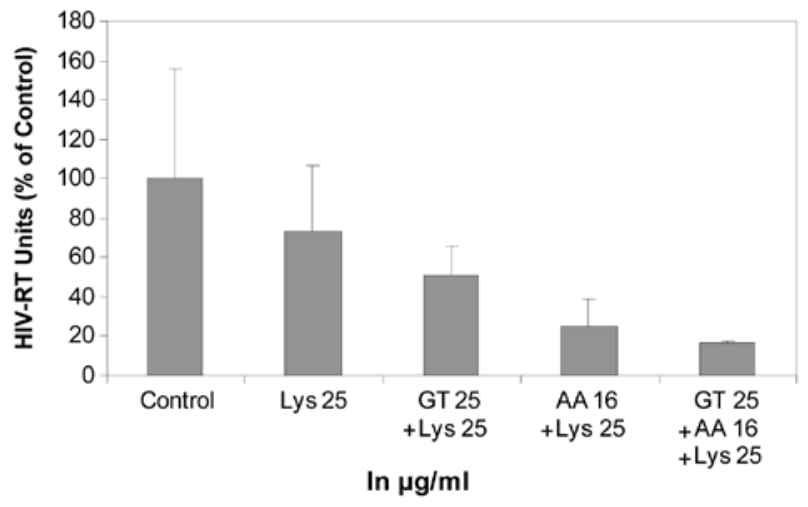

Figure 2. Effect of lysine (Lys), green tea extract (GT) and ascorbic acid (AA) on HIV-1 RT level in the culture supernatant of H9/HTLV-III ${ }_{B}$ cells. Shown is the residual RT level as a percentage of the control. The combination of GT and Lys at $25 \mu \mathrm{g} / \mathrm{ml}$ each achieved a greater RT reduction relative to the control than an identical concentration of Lys alone, but this effect was insignificant ( $\mathrm{p}=0.25$ ). The addition of AA at $16 \mu \mathrm{g} / \mathrm{ml}$ to the GT and Lys combination further reduced the RT to a marginally significant level $(\mathrm{p}=0.06)$.

the ratio of total cell protein/HIV-1 RT units (data not shown). When $25 \mu \mathrm{g} / \mathrm{ml}$ Lys was combined with $25 \mu \mathrm{g} / \mathrm{ml} \mathrm{GT}$, the RT level was reduced to a greater degree compared to the control than was observed with Lys alone at the same concentration (reduction to $51 \%$ of control, p=0.25) (Fig. 2). When $25 \mu \mathrm{g} / \mathrm{ml}$ Lys was combined with $16 \mu \mathrm{g} / \mathrm{ml} \mathrm{AA}$, the RT was reduced to $25 \%(\mathrm{p}=0.09$ ) of the control value. Adding $16 \mu \mathrm{g} / \mathrm{ml}$ AA to the combination of Lys and GT further decreased the RT to $17 \%$ of the control value, an effect that was marginally significant $(\mathrm{p}=0.06)$. The ratio of total cell protein/HIV-1 RT units was not significantly affected by the combination of nutrients, as shown in Table I.

Effect of proline, arginine, lysine, green tea extract and ascorbic acid on HIV-1 RT level in culture supernatant and ratio of total cell protein/HIV-1 RT units. The combination of $18 \mu \mathrm{g} / \mathrm{ml}$ Pro, $12 \mu \mathrm{g} / \mathrm{ml}$ Arg and $25 \mu \mathrm{g} / \mathrm{ml}$ Lys had a slight but insignificant effect on extracellular HIV-1 RT levels compared to the control value. The addition of $25 \mu \mathrm{g} / \mathrm{ml}$ GT to this combination had no significant effect. However, the addition of $32 \mu \mathrm{g} / \mathrm{ml}$ AA to the mixture of GT, Pro, Arg

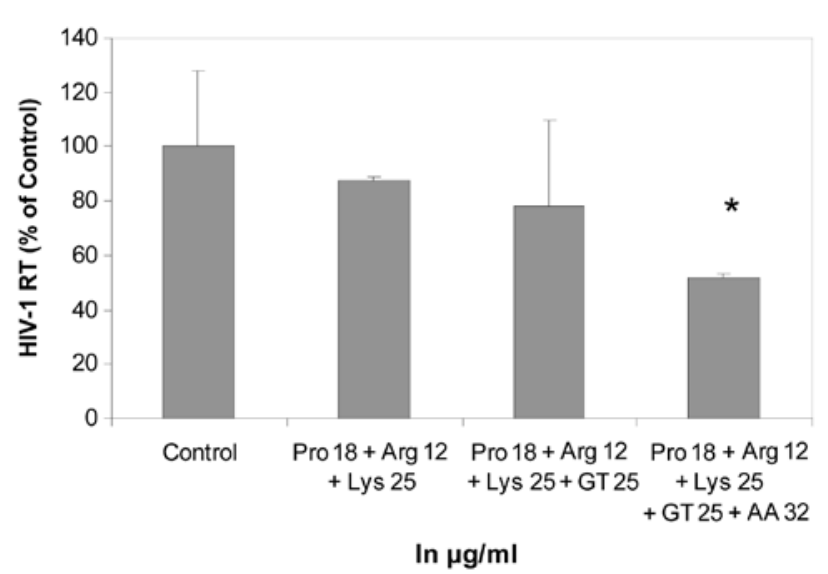

Figure 3. Effect of proline (Pro), arginine (Arg), lysine (Lys), green tea extract (GT) and ascorbic acid (AA) on HIV-1 RT level in the culture supernatant of $\mathrm{H} 9 / \mathrm{HTLV}-\mathrm{III}_{\mathrm{B}}$ cells. Shown is the residual RT level as a percentage of the control. The combination of $18 \mu \mathrm{g} / \mathrm{ml}$ Pro, $12 \mu \mathrm{g} / \mathrm{ml}$ Arg and $25 \mu \mathrm{g} /$ $\mathrm{ml}$ Lys had a slight but insignificant effect on the HIV-1 RT level relative to the control. The addition of $25 \mu \mathrm{g} / \mathrm{ml} \mathrm{GT}$ had no significant effect. However, the addition of AA at $32 \mu \mathrm{g} / \mathrm{ml}$ to the GT, Pro, Arg and Lys mixture had a significant inhibitory effect $(\mathrm{p}=0.05)$ on the HIV-1 RT level. * $\mathrm{p}=0.05$ or better compared to the control.

and Lys had a significant inhibitory effect (49\% reduction, $\mathrm{p}=0.05$ ) on HIV-1 RT, as shown in Fig. 3. The ratio of total protein/HIV-1 RT units was insignificantly increased to $112 \%$ of the control value $(\mathrm{p}=0.28)$ with this combination of nutrients, as shown in Table I.

Effect of nutrient mixture on HIV-1 RT level in culture supernatant and ratio of total cell protein/HIV-1 RT units. Since individual nutrients and their combinations exerted anti-HIV effects, a nutrient mixture (NM) containing these components was also tested. The NM suppressed HIV-1 production in a dose-response fashion $(\mathrm{r}=-0.8204, \mathrm{p}=0.0002)$, with extracellular viral RT significantly decreased at $200 \mu \mathrm{g} / \mathrm{ml} \mathrm{NM}$ to $15 \%$ of the control value ( $\mathrm{p}=0.006)$, as shown in Fig. 4 . The selectivity index (ratio of total cell protein/HIV-1 RT units) increased with an increase in NM concentration $(\mathrm{r}=0.7672$, $\mathrm{p}=0.0008)$, reaching $220 \%(\mathrm{p}=0.009)$ of the control value at $200 \mu \mathrm{g} / \mathrm{ml} \mathrm{NM}$, as shown in Table I. 


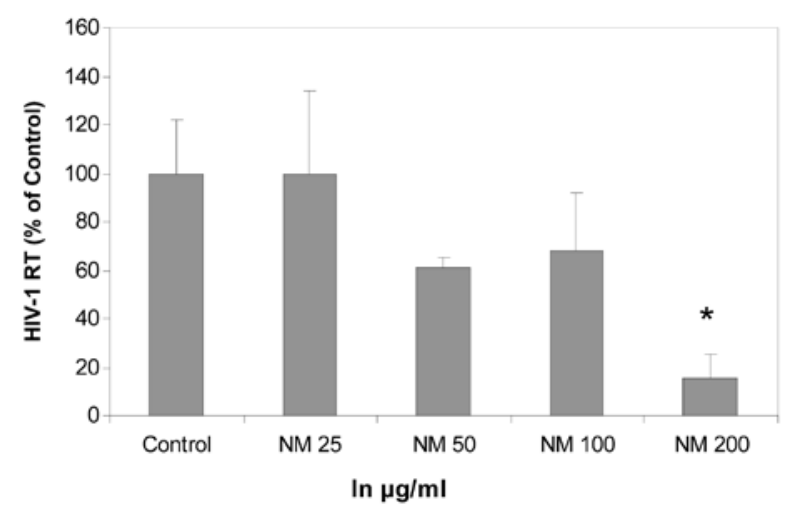

Figure 4. Effect of nutrient mixture (NM) on HIV-1 RT level in the culture supernatant of $\mathrm{H} 9 / \mathrm{HTLV}-\mathrm{III}_{\mathrm{B}}$ cells. Shown is the residual RT level as a percentage of the control. NM suppressed the HIV-1 RT level in a dosedependent fashion (correlation $\mathrm{r}=-0.8204, \mathrm{p}=0.0002$ ), with $\mathrm{p}=0.006$ at $200 \mu \mathrm{g} / \mathrm{ml}$ NM relative to the control.

Effect of azidothymidine on HIV-1 RT level in culture supernatant and ratio of total cell protein/HIV-1 RT units. Azidothymidine (AZT) reduced HIV-1 RT units in the culture supernatant with an increased concentration (coefficient $r=-0.5122, p=0.0997$ ), although the reduction at low to moderate concentrations $(0.5-1.0 \mu \mathrm{g} / \mathrm{ml})$ was insignificant. A reduction in $\mathrm{RT}$ to $40 \%$ of the control value $(\mathrm{p}=0.02)$ was noted at $2.0 \mu \mathrm{g} / \mathrm{ml} \mathrm{AZT}$, as shown in Fig. 5. The ratio of total protein/HIV-1 RT units slightly increased with an increase in AZT concentration (coefficient $r=0.3255, p=0.3018$ ), but did not reach statistical significance, as shown in Table I.

Studies in the latently infected ACH-2 cell line

Effect of nutrient mixture, green tea and ascorbic acid on $H I V-1$ RT level in culture supernatant and ratio of total cell protein/HIV-1 RT units in PMA-stimulated cells. To substantiate our observations in other chronically HIV-infected lines, the effects of NM and two of its key individual components (AA and GT) were evaluated in a HIV-latently infected T cell line, $\mathrm{ACH}-2$, that can be induced with the tumor promoter PMA to release HIV into the culture supernatant. Fig. 6 shows that, under uninduced conditions, $\mathrm{ACH}-2$ released very low levels of extracellular viral RT, which were increased 40-fold

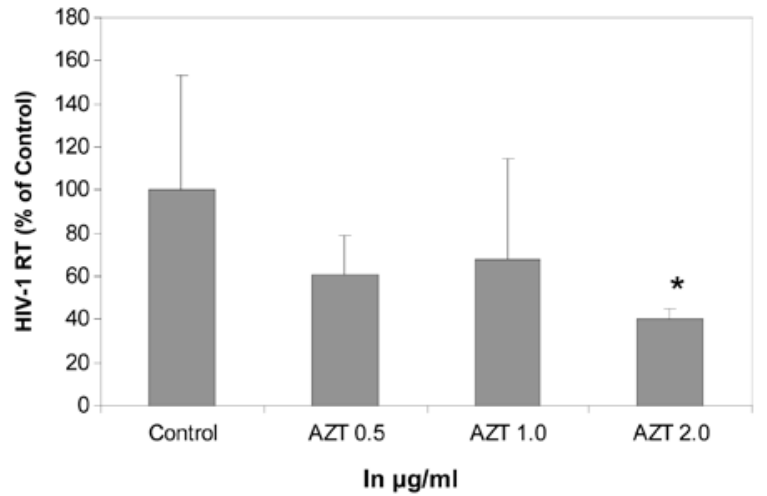

Figure 5. Effect of azidothymidine (AZT) on HIV-1 RT level in the culture supernatant of $\mathrm{H} 9 / \mathrm{HTLV}-\mathrm{III}_{\mathrm{B}}$ cells. Shown is the residual RT level as a percentage of the control. AZT suppressed the HIV-1 RT level with an increased concentration (coefficient $\mathrm{r}=-0.5122, \mathrm{p}=0.0997$ ), achieving a significant reduction in $\mathrm{RT}$ of $40 \%$ of the control value $(\mathrm{p}=0.02)$ only at the higher concentration of $2 \mu \mathrm{g} / \mathrm{ml}$. * $\mathrm{p}=0.05$ or better relative to the control.

upon stimulation with PMA for $24 \mathrm{~h}$. When ACH-2 cells were pre-treated with NM for $24 \mathrm{~h}$ and then stimulated with PMA for $24 \mathrm{~h}$ in the presence of NM, dose-dependent suppression of HIV-1 production was evident, with the extracellular RT level reduced to $27.9 \%$ of the PMA-induced control value $(\mathrm{p}=0.029)$ at $100 \mu \mathrm{g} / \mathrm{ml} \mathrm{NM}$. The total cell protein/HIV-1 RT ratio increased with NM concentration, reaching 373\% $(\mathrm{p}=0.026)$ of the PMA-induced control value at $100 \mu \mathrm{g} / \mathrm{ml}$ NM, as shown in Table II.

Under identical conditions as NM, pre-treatment with GT alone at a concentration $(25 \mu \mathrm{g} / \mathrm{ml})$ equivalent to that contained in $\mathrm{NM}$ at $100 \mu \mathrm{g} / \mathrm{ml}$ did not confer a significant reduction in the viral RT level $(\mathrm{p}=0.093)$, as shown in Fig. 6. A 2-fold higher concentration $(50 \mu \mathrm{g} / \mathrm{ml})$ of GT alone was required to produce significant suppression of RT, with the level reduced to $43.6 \%$ of the control value $(p=0.05)$. The ratio of total cell protein/HIV-1 RT increased with an increase in GT concentration, reaching $248 \%$ of the control value $(\mathrm{p}=0.22)$ at $50 \mu \mathrm{g} /$ $\mathrm{ml}$ GT, as shown in Table II.

Fig. 6 also shows the effect of AA alone. Under the same conditions as above, pre-treatment with AA alone at a concentration $(16 \mu \mathrm{g} / \mathrm{ml})$ equivalent to that contained in $\mathrm{NM}$ at $100 \mu \mathrm{g} / \mathrm{ml}$ did not significantly affect viral RT activity.

Table II. Effect of test agents on the mean ratio of total cell protein/HIV-1 RT units in PMA-induced ACH-2 cells.

\begin{tabular}{lccc}
\hline Test agents $(\mu \mathrm{g} / \mathrm{ml})$ & Mean ratio & Standard deviation & Percentage of control \\
\hline Control + PMA & 1.21 & 0.042 & 100.0 \\
NM 50 + PMA & 2.90 & 1.058 & 78.9 \\
NM 100 + PMA & 4.53 & 0.226 & $373.0^{\mathrm{a}}$ \\
GT 25 + PMA & 2.82 & 1.005 & 74.8 \\
GT 50 + PMA & 3.03 & 0.951 & $248.5^{\mathrm{b}}$ \\
AA 16 + PMA & 1.31 & 9.600 & 107.8 \\
AA 32 + PMA & 1.91 & 0.177 & 157.0 \\
AA 64 + PMA & 2.02 & 0.000 & $166.6^{\mathrm{c}}$ \\
\hline
\end{tabular}

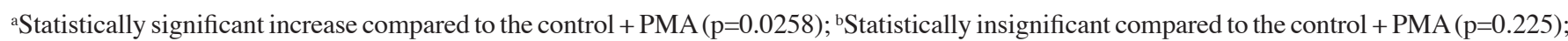
${ }^{c}$ Statistically significant increase compared to the control + PMA ( $\left.\mathrm{p}=0.0233\right)$. NM, nutrient mixture; GT, green tea extract; AA, ascorbic acid. 


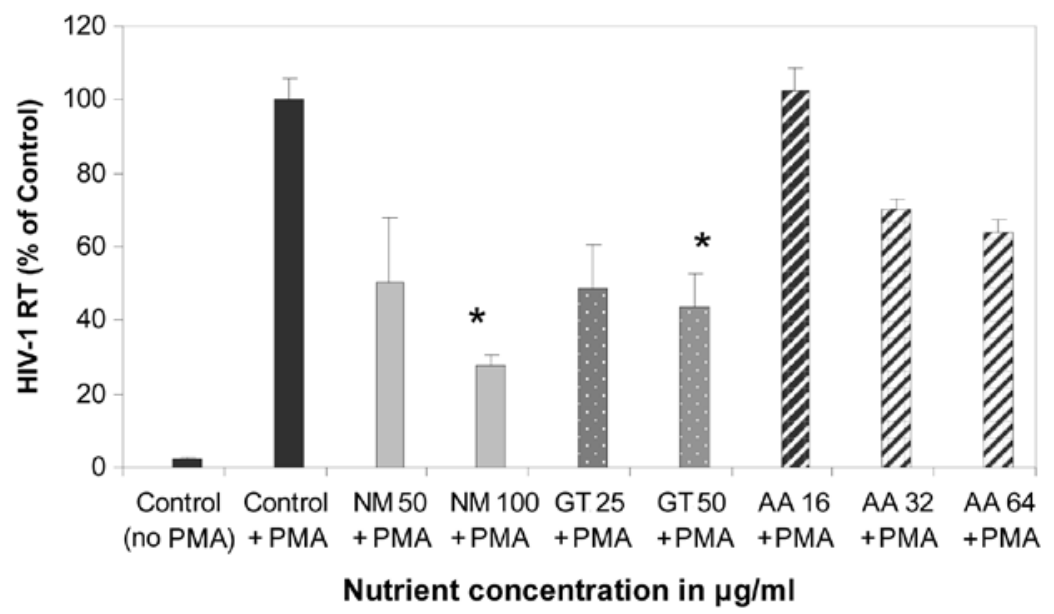

Figure 6. Effects of nutrient mixture (NM), green tea extract (GT) and ascorbic acid (AA) on HIV-1 RT level in the culture supernatant of ACH-2 cells stimulated with PMA. Shown is the RT level as a percentage of the PMA-stimulated control. NM suppressed RT induction with an increased concentration, with a significant reduction of the RT level at $100 \mu \mathrm{g} / \mathrm{ml}(\mathrm{p}=0.0293)$ compared to insignificant suppression by equivalent concentrations of GT ( $\mathrm{p}=0.0925 \mathrm{at} 25 \mu \mathrm{g} / \mathrm{ml})$ or AA ( $\mathrm{p}=0.6552$ at $16 \mu \mathrm{g} / \mathrm{ml})$ contained in the mixture. A 2-fold higher concentration of GT alone achieved significant suppression $(\mathrm{p}=0.0504 \mathrm{at} 50 \mu \mathrm{g} / \mathrm{ml})$, while 2- to 4 -fold higher concentrations of AA alone did not ( $\mathrm{p}=0.0755$ at $32 \mu \mathrm{g} / \mathrm{ml}$ and $\mathrm{p}=0.0723$ at $64 \mu \mathrm{g} / \mathrm{ml} \mathrm{AA}$ ). "p=0.05 or better relative to the control.

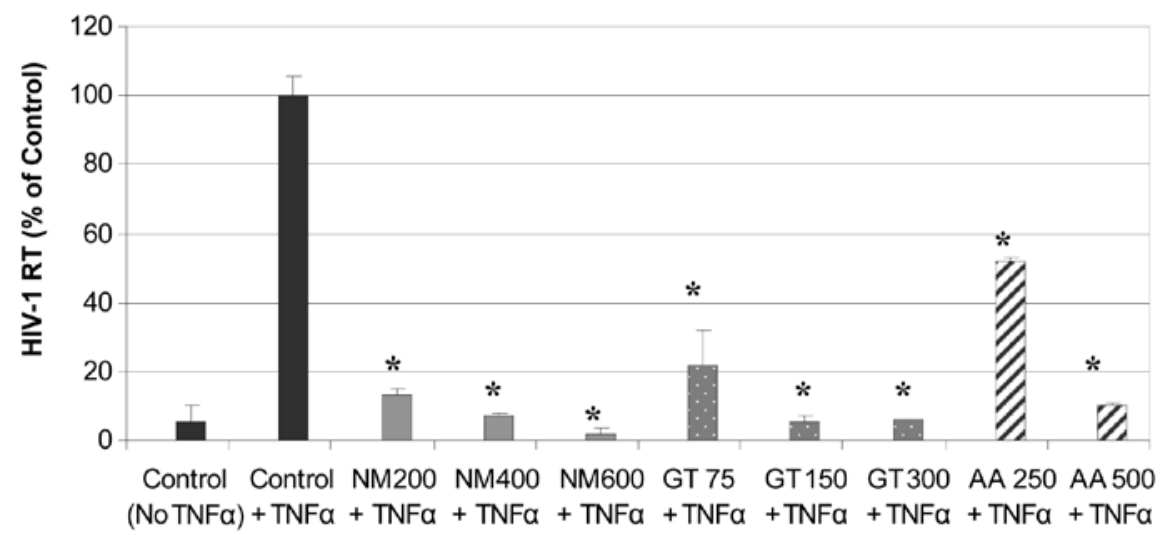

Nutrient Concentration in $\mu \mathrm{g} / \mathrm{ml}$

Figure 7. Effects of nutrient mixture (NM), green tea extract (GT) and ascorbic acid (AA) on the HIV-1 RT level in the culture supernatant of ACH-2 cells stimulated with TNF- $\alpha$. Shown is the RT level as a percentage of the TNF- $\alpha$-stimulated control. NM, GT and AA suppressed RT induction in a dose-dependent fashion. NM significantly suppressed the RT level at $200 \mu \mathrm{g} / \mathrm{ml}(\mathrm{p}=0.009), 400 \mu \mathrm{g} / \mathrm{ml}$ ( $\mathrm{p}=0.026)$ and $600 \mu \mathrm{g} / \mathrm{ml}$ ( $\mathrm{p}=0.014)$. Similarly, GT significantly suppressed the RT level at $75 \mu \mathrm{g} / \mathrm{ml}(\mathrm{p}=0.015), 150 \mu \mathrm{g} / \mathrm{ml}(\mathrm{p}=0.009)$ and $300 \mu \mathrm{g} / \mathrm{ml}(\mathrm{p}=0.025)$. Moreover, AA significantly suppressed the RT level at $250 \mu \mathrm{g} / \mathrm{ml}(\mathrm{p}=0.014)$ and $500 \mu \mathrm{g} / \mathrm{ml}(\mathrm{p}=0.02) .{ }^{*} \mathrm{p}=0.05$ or better relative to the control.

Pre-treatment with 32 and $64 \mu \mathrm{g} / \mathrm{ml}$ AA reduced the RT level by $30 \%(\mathrm{p}=0.08)$ and $36 \%(\mathrm{p}=0.07)$, respectively, but this was not statistically significant. The ratio of total cell protein/ HIV-1 RT units increased with an increase in AA concentration, reaching significance at $64 \mu \mathrm{g} / \mathrm{ml} \mathrm{AA}$ (Table II).

Effect of nutrient mixture, green tea and ascorbic acid on $H I V-1$ RT level in culture supernatant and ratio of total cell protein/HIV-1 RT units in TNF- $\alpha$-stimulated cells. To confirm and extend the above observations using a different inducer and higher concentrations (more data points) of comparative conditions in ACH-2 cells, the effects of the nutrient mixture and its key components following cell stimulation with the inflammatory cytokine TNF- $\alpha$ were evaluated. Fig. 7 shows the nutrient effects on HIV-1 RT, and Table III displays the total cell protein/HIV-1 RT ratio. Exposure of ACH-2 cells to TNF- $\alpha$ for $48 \mathrm{~h}$ resulted in an approximate 19-fold induction of virus (Fig. 7). Pre-treatment of cells with 200-600 $\mu \mathrm{g} / \mathrm{ml}$ NM for $24 \mathrm{~h}$ followed by stimulation with TNF- $\alpha$ for $48 \mathrm{~h}$ in the presence of NM conferred a dose-dependent suppression of HIV production, with the extracellular RT level reduced to $2.04 \%$ of the TNF- $\alpha$-stimulated control at the highest dose tested ( $\mathrm{p}=0.013$ at $600 \mu \mathrm{g} / \mathrm{ml} \mathrm{NM}$ ) (Fig. 7). The total protein/ HIV-1 RT ratio also progressively increased with an increase in NM concentration (Table III). Under similar conditions as those used with the NM, pre-treatment with 75-300 $\mu \mathrm{g} /$ ml GT alone also achieved significant suppression of HIV-1 production (Fig. 7) with an increased protein/HIV-1 ratio (Table III), although the final RT level at a concentration $(150 \mu \mathrm{g} / \mathrm{ml})$ equivalent to that contained in NM at $600 \mu \mathrm{g} /$ $\mathrm{ml}$ was 2.5 -fold higher than that in NM (5.16 vs. $2.04 \%$ of the TNF- $\alpha$-stimulated control; Fig. 7). Under the same conditions as above, pre-treatment with 250 and $500 \mu \mathrm{g} / \mathrm{ml}$ AA achieved significant suppression of HIV-1 RT; however, 
Table III. Effect of test agents on the mean ratio of total cell protein/HIV-1 RT units in TNF- $\alpha$-induced ACH-2 cells.

\begin{tabular}{lrrr}
\hline Test agents $(\mu \mathrm{g} / \mathrm{ml})$ & Mean ratio & Standard deviation & Percentage of control \\
\hline Control + TNF- $\alpha$ & 1.55 & 0.08 & 100 \\
NM 200 + TNF- $\alpha$ & 10.39 & 2.01 & 667 \\
NM 400 + TNF- $\alpha$ & 15.28 & 3.24 & 980 \\
NM 600 + TNF- $\alpha$ & 86.76 & 71.39 & 5730 \\
GT 75 + TNF- $\alpha$ & 7.04 & 2.71 & 459 \\
GT 150 + TNF- $\alpha$ & 23.16 & 5.95 & 1484 \\
GT 300 + TNF- $\alpha$ & 7.61 & 2.22 & 487 \\
AA 250 + TNF- $\alpha$ & 2.79 & 0.28 & 179 \\
AA 500 & 11.36 & 1.75 & 729
\end{tabular}

NM, nutrient mixture; GT, green tea extract; AA, ascorbic acid.

the level of suppression was lower than that noted with the nutrient mixture (Fig. 7). The total protein/HIV-1 RT ratio also increased with an increase in AA concentration (Table III).

\section{Discussion}

Due to the lifelong nature of HIV treatment, there is a need to find a relatively non-toxic agent to confer sustained inhibition of the virus in chronic infection. Our study indicates that the relatively non-toxic individual micronutrients tested had a significant suppressive effect on virus production in HIV-1 chronically infected $\mathrm{T}$ lymphocytes; moreover, the micronutrients in combination significantly enhanced the suppression of HIV-1 RT. For example, GT and AA individually suppressed HIV-1 RT with an increase in concentration. However, combining GT $(25 \mu \mathrm{g} / \mathrm{ml})$ with increasing concentrations of AA (16-64 $\mu \mathrm{g} / \mathrm{ml})$ incrementally enhanced the suppressive activity of GT alone at the extracellular RT level. When GT $(25 \mu \mathrm{g} / \mathrm{ml})$ was combined with Lys $(25 \mu \mathrm{g}$ / $\mathrm{ml})$, the combination showed a greater reduction in RT than did Lys alone. Adding AA $(16 \mu \mathrm{g} / \mathrm{ml})$ to the combination of Lys and GT decreased the RT even further, to a marginally significant level. By combining these constituents in an NM, a greater reduction in $\mathrm{RT}$ was conferred than with equivalent concentrations of the key individual components. This cooperative effect was confirmed with AA, GT and the NM in an independent line of latently infected cells stimulated with PMA or TNF- $\alpha$. In both cell lines, this effect was virusspecific and was not due to micronutrient-induced host-cell toxicity, since the selectivity index (ratio of total cell protein/ HIV-1 RT units) did not decrease compared to the control values; indeed, in some cases there was a significant increase.

AZT, a known antiretroviral (ARV) drug, in the concentrations tested, only reduced RT to $40 \%(\mathrm{p}=0.02)$ of the control value at $2 \mu \mathrm{g} / \mathrm{ml}$. This is a modest effect compared to the effects of this ARV drug in acute infection, where it is known to confer greater levels of virus suppression. In acute infection, AZT, functioning as a DNA chain terminator, interferes with the reverse transcription reaction (i.e., RNA-dependent DNA synthesis), which is its prime target of antiviral action.
The low level of suppression by AZT of RT production (i.e., the RT level) in the culture supernatant of chronically infected cells is consistent with previous studies $(19,20)$ showing the limited ability of AZT to block virus expression from integrated proviral DNA in chronically or latently infected cells.

In contrast, the ability of the NM and some of its components to suppress HIV production in chronically infected cells more extensively than AZT sets this class of compounds apart from AZT-like ARVs in controlling HIV multiplication in persistent infection. The effects of the NM in acute infection remain unclear, since the main focus of our study involved chronic or latent infection. However, given the components in the mixture, it is likely to be effective in acute infection. In this respect, it should be noted that micronutrients such as ascorbate (vitamin C) have also been shown to suppress HIV replication in acutely infected cells (9), and epigallocatechin gallate (EGCG), a component of GT, has been reported to inhibit HIV binding to host cells $(11,21)$. This broad-based anti-HIV action of specific micronutrients at various phases of viral infection combined with their minimal cellular toxicity suggests the potential value of these natural compounds in controlling HIV infection. Large-scale clinical studies of micronutrients in HIV infection are therefore warranted.

The mechanisms underlying the cooperative suppression of HIV by micronutrients are as yet unknown. Multiple mechanisms are possibly involved, all contributing to the cooperative suppression. The nutrient mixture was formulated based on the targeting of different physiological processes involved in infectious disease at the cellular level. Ascorbic acid, a main component of the NM, was previously reported to inhibit HIV replication in lymphocytic cells $(9,11)$, an effect that was localized to a post-transcriptional step in virus replication (10). Ascorbate is known to kill cancer cells through a pro-oxidant effect, and has been reported to beneficially modulate HIV/AIDS clinically (15). Dr Cathcart reported clinical improvement and improved CD4 counts while treating over $250 \mathrm{HIV}$-positive patients, including those with AIDS or AIDS-related complex. Upon treatment with large doses of ascorbate (based on bowel tolerance), he noted that vitamin $\mathrm{C}$ was more rapidly metabolized depending on the severity of the disease, thus necessitating a higher vitamin $\mathrm{C}$ dosage (15). 
Ascorbate has been demonstrated to kill HIV directly in both blood and culture medium (22), and preferentially lessens the viability of HIV-infected cells to reproduce or survive (23). Ascorbate has also been shown to improve the clinical status of HIV-infected patients, such as those who develop myopathy secondary to AZT therapy (24), and to lower oxidative stress (16). De la Asuncion et al suggested that AZT-associated myopathy was due to oxidative damage to DNA in mitochondria in muscle tissue, which ascorbate was shown to protect against (24).

Another major component of NM is GT, which is enriched in polyphenols such as EGCG. GT was found to have anti-HIV effects. EGCG has been shown to have anti-HIV-1 activity in human lymphocytes in vitro by inhibiting the biochemical activity of HIV-1 RT, resulting in a decrease in HIV-1 p24 antigen concentration (25). It has also been shown to prevent the binding of HIV-1 glycoprotein 120 to the CD4 molecule on $\mathrm{T}$ cells $(11,21)$.

Natural inhibitors of extracellular matrix proteolysis, such as lysine, proline and ascorbic acid, were selected for inclusion in the NM, since they can block viral spread by inhibiting the protease digestion of collagen, thus preventing the destruction of surrounding connective tissue, and also support the production of collagen to optimize the strength and integrity of connective tissue. Rath and Pauling (26) suggested targeting plasmin-mediated mechanisms using nutrients such as lysine and lysine analogs. Manganese and copper are also essential cofactors in collagen formation. Collagen stability is also modulated by $\mathrm{N}$-acetyl cysteine through the inhibition of metalloproteinase (MMP) activity (27) and tumor cell invasion (28). Selenium has been shown to interfere with the migration of endothelial cells through the extracellular matrix (ECM) (28), as well as to inhibit MMP expression and tumor invasion (29). In previous studies, we showed that NM not only inhibited virus-associated neuraminidase activity and viral nuclear antigen production (30), but also inhibited extracellular invasive parameters such as MMP-2 and -9 secretion and the invasion of influenza A virus in MDCK and Vero cells in vitro (31).

In conclusion, the relatively non-toxic micronutrients tested have, especially in combination, potential in the treatment of HIV infection by selectively blocking virus production in HIV-1 chronically and latently infected T lymphocytes. Since these studies on HIV-1 RT were carried out in vitro, the test concentrations of the nutrients such as GT were of a higher magnitude than the plasma levels achieved with the nutrients. Though plasma concentrations of EGCG are much lower than orally administered concentrations, they have been reported to be as high as 4.4 and $7.4 \mu \mathrm{mol} / \mathrm{l}$ (32), corresponding to 1.8 and $3.2 \mu \mathrm{g} / \mathrm{ml}$ EGCG, respectively. GT extract contains approximately $80 \%$ polyphenol. Of note, quercetin and NM have both been shown to increase EGCG plasma levels (33). In addition, high levels of tea polyphenols can be achieved in the body when GT is frequently consumed (34). In vivo studies of these nutrient combinations on HIV-1 infection are indicated.

\section{Acknowledgements}

This research study was funded by the Dr Rath Health Foundation (Plantation, FL, USA), a non-profit organization.
The following reagents were obtained through the NIH AIDS Research and Reference Reagent Program, Division of AIDS, NIAID, NIH: i) H9/HTLV-III ${ }_{B}$ NIH 1983, cat. no. 400 from Dr Robert Gallo, contributor; ii) ACH-2, cat. no. 349 from Dr Thomas Folks, and iii) Zidovudine (AZT), cat. no. 3485 from the Division of AIDS, NIAID, contributor.

\section{References}

1. World Health Organization: HIV/AIDS data and statistics. http:// www.who.int/hiv/data/en/. Accessed Dec 18, 2008.

2. Hahn BH, Shaw GM, De Cock KM and Sharp PM: AIDS as a zoonosis: scientific and public health implications. Science 287: 607-614, 2000.

3. Sleaseman JW and Goodenow MM: HIV-1 infection. J Allergy Clin Immunol 111: S582-S592, 2003.

4. Hogg RS, Yip B, Chan KJ, Wood E, Craib KJ, O'Shaughnessy MV and Montaner JS: Rates of disease progression by baseline CD4 cell count and viral load after initiating triple-drug therapy. JAMA 286: 2568-2577, 2001.

5. Carr A, Samaras K, Chisholm DJ and Cooper DA: Pathogenesis of HIV-1 protease inhibitor-associated peripheral lipodystrophy, hyperlipidemia and insulin resistance. Lancet 351: 1881-1883, 1998.

6. Beach RS, Mantero-Atienza E, Shor-Posner G, Javier JJ, Szapocznik J, Morgan R, Sauberlich HE, Cornwell PE, Eisdorfer C and Baum MK: Specific nutrient abnormalities in asymptomatic HIV-1 infection. AIDS 6: 701-708, 1992.

7. Gray RH: Similarities between AIDS and PCM (Letter). Am J Public Health 73: 1332, 1984.

8. Srinivas A and Dias BF: Antioxidants in HIV-positive children. Indian J Pediatr 75: 347-350, 2008.

9. Harakeh S, Jariwalla RJ and Pauling L: Suppression of human immunodeficiency virus replication by ascorbate in chronically and acutely infected cells. Proc Natl Acad Sci USA 87: 7245-7249, 1990.

10. Harakeh S, Niedzwiecki A and Jariwalla RJ: Mechanistic aspects of ascorbate inhibition of human immunodeficiency virus. Chem Biol Interact 91: 207-215, 1994.

11. Harakeh S and Jariwalla RJ: Comparative study of the anti-HIV activities of ascorbate and thiol-containing reducing agents in chronically HIV-infected cells. Am J Clin Nutr 54: S1231-S1235, 1991.

12. Kawai K, Tsuno MD, Kitayama J, Okaji Y, Yazawa K, Asakage M, Hori N, Watanabe T, Takahashi K and Nagawa MD: Epigallocatechin gallate attenuates adhesion and migration of $\mathrm{CD}^{+} \mathrm{T}$ cells by binding to CD11b. J Allergy Clin Immunol 113: 1211-1217, 2004.

13. Nakane $\mathrm{H}$ and Ono $\mathrm{K}$ : Differential inhibition of HIV-reverse transcriptase and various DNA and RNA polymerases by some catechin derivatives. Nuclei Acids Symp Ser 21: 115-116, 1989.

14. Jariwalla RJ and Harakeh S: Antiviral and immunomodulatory activities of ascorbic acid. In: Subcellular Biochemistry. Vol 25. Harris JR (ed). Plenum Press, New York, pp215-231, 1996.

15. Cathcart R: Vitamin $C$ treatment of acquired immune deficiency syndrome (AIDS). Med Hypotheses 14: 423-433, 1984.

16. Allard JP, Aghadassi E, Chau J, Tam C, Kovacs CM, Salit LE and Walmsley SL: Effects of vitamin E and C supplementation on oxidative stress and viral load in HIV-infected subjects. AIDS 12: 1653-1659, 1998.

17. Muller F, Svardal AM, Nordoy I, Berge RK, Aukrust P and Froland SS: Virological and immunological effects of antioxidant treatment in patients with HIV infection. Eur J Clin Invest 30: 905-914, 2000.

18. Skehan P, Storeng R, Scudiero D, Monks A, McMahon J, Visica D, Warren JT, Vokesch H, Kenney S and Boyd MR: New colorimetric cytotoxicity assay for anti-cancer drug screening. J Natl Cancer Inst 82: 1107-1112, 1990.

19. Poli G, Orenstein JM, Kinter A, Folks TM and Fauci AS: Interferon-alpha but not AZT suppresses HIV expression in chronically infected cell lines. Science 224: 575-577, 1989.

20. Harakeh S and Jariwalla RJ: Ascorbate effect on cytokine stimulation of HIV production. Nutrition 11: 684-687, 1995.

21. Williamson MP, McCormick TG, Nance CL and Shearer WT: Epigallocatechin gallate, the main polyphenol in green tea, binds to the T-cell receptor, CD4: potential for HIV-1 therapy. J Allergy Clin Immunol 118: 1369-1374, 2006. 
22. Rawal B, Bartolini F and Vyas G: In vitro inactivation of human immunodeficiency virus by ascorbic acid. Biologicals 23: 75-81, 1995.

23. Rivas C, Guaiquil VV, Velasquez F, Borquez-Ojeda O Carcamo J, Concha I and Golde D: Increased uptake and accumulation of vitamin $\mathrm{C}$ in human immunodeficiency virus 1-infected hematopoietic cell lines. J Biol Chem 272: 5814-5820, 1997.

24. De la Asuncion J, del Olmo ML, Sastre J, Millán A, Pellin A, Pallardó FV and Viña J: AZT treatment induces molecular and ultrastructural oxidative damage to muscle mitochondria. Prevention by antioxidant vitamins. J Clin Invest 102: 4-9, 1998.

25. Fassina G, Buffa A, Benelli R, Varnier OE, Noonan DH and Albini A: Polypheonolic antioxidant (-)-epigallocatechin-3gallate from green tea as a candidate anti-HIV agent. AIDS 16 : 939-941, 2002.

26. Rath $\mathrm{M}$ and Pauling L: Plasmin-mediated proteolysis and the role of apoprotein(a), lysine and synthetic analogs. Orthomol Med 7: 17-23, 1992.

27. Kawakami S, Kageyama Y, Fujii Y, Kihara K and Oshima H: Inhibitory effects of $\mathrm{N}$-acetyl cysteine on invasion and MMP 9 production of T24 human bladder cancer cells. Anticancer Res 21: 213-219, 2001.

28. Morini M, Cai T, Aluigi MG, Noonan DM, Masiello I, De Floro S, D'Agostinin F, Albini A and Fassina G: The role of the thiol $\mathrm{N}$-acetyl cysteine in the prevention of tumor invasion and angiogenesis. Int J Biol Markers 14: 268-271, 1999.
29. Yoon SO, Kim MM and Chung AS: Inhibitory effects of selenite on invasion of HT 1080 tumor cells. J Biol Chem 276: 20085-20092, 2001.

30. Jariwalla RJ, Roomi MW, Gangapurkar B, Kalinovsky T, Niedzwiecki A and Rath M: Suppression of influenza A virus nuclear antigen production and neuraminidase activity by a nutrient mixture containing ascorbic acid, green tea extract and amino acids. Biofactors 31: 1-15, 2007.

31. Roomi MW, Jariwalla RJ, Kalinovsky T, Roomi N, Niedzwiecki A and Rath M: Inhibition of cellular invasive parameters in influenza A virus-infected MDCK and Vero cells by a nutrient mixture. Biofactors 32: 1-15, 2008.

32. Manach C, Williamson G, Morand C, Scalbert A and Rémésy C: Bioavailability and bioefficacy of polyphenols in humans, 1. Review of 97 bioavailability studies. Am J Nutr 81: S230-S242, 2005.

33. Gawande S, Kale A and Kotwal S: Effect of nutrient mixture and black grapes on the pharmacokinetics of orally administered (-) epigallocatechin-3-gallate from green tea extract: a human study. Phytother Res 22: 802-808, 2008.

34. Suganuma M, Okabe S, Oniyama M, Tada Y, Ito H and Fujiki H: Wide distribution of $\left[{ }^{3} \mathrm{H}\right](-)$-epigallocatechin gallate, a cancer preventive tea polyphenol, in mouse tissue. Carcinogenesis 19: 1771-1776, 1998. 
